\title{
APPLICATION OF BIODEGRADABLE FILMS IN GUAVA TO CONTROL FRUIT FLIES $^{1}$
}

\author{
JOÁLISSON GONÇALVES DA SILVA², CARLOS HENRIQUE DE BRITO³ , LAÉSIO PEREIRA MARTINS ${ }^{4}$, \\ ROBÉRIO DE OLIVEIRA ${ }^{2 *}$, LUCAS RODRIGUES GOMES ${ }^{2}$
}

\begin{abstract}
Psidium guajava L. is widely cultivated in tropical and subtropical regions of the world. This research aimed to evaluate the effect of the use of biodegradable coating associated with different temperatures on the quality of 'Paluma' guava fruits infested by Ceratitis capitata Wiedemann on its control. The experiment was conducted in a completely randomized design in a $3 \times 6 \times 6$ factorial scheme with three replicates. The factors under study were three temperatures $10{ }^{\circ} \mathrm{C}, 15^{\circ} \mathrm{C}$, and $23{ }^{\circ} \mathrm{C}$ (room temperature) with six treatments each: Control - WoO WoC (without oviposition and without coating); WiO WoC (with oviposition and without coating); $\mathrm{WiO}+\mathrm{CCFO}$ (without oviposition and coating containing fennel oil); WiO+CCFO (with oviposition and coating containing fennel oil); $\mathrm{WoO}+\mathrm{CCBO}$ (without oviposition and coating containing basil oil); $\mathrm{WoO}+\mathrm{CCBO}$ (with oviposition and coating containing basil oil). The treatments were evaluated in six periods according to the factors already mentioned. Physical, physical-chemical, biochemical and subjective evaluations were performed. Data were submitted to analysis of variance based on the significance of the F test and, in order to test the effect of storage days, the results were submitted to regression analysis. The use of biodegradable coating associated with low temperatures minimizes the loss of mass and promotes less loss of fruit firmness. The presence of $C$. capitata larvae depreciates the physical-chemical quality of guava fruits, but the coating process associated with low temperatures is lethal to eggs and larvae of $C$. capitata, reducing damage in fruits infested.
\end{abstract}

Keywords: Psidium guajava. Ceratitis capitata. Biodegradable coating. Temperatures.

\section{APLICAÇÃO DE FILMES BIODEGRADÁVEIS EM GOIABA PARA CONTROLE DE MOSCA-DAS- FRUTAS}

RESUMO - Psidium guajava L. é amplamente cultivada nas diversas regiões tropicais e subtropicais do mundo. Esta pesquisa teve como objetivo avaliar o efeito do uso de recobrimento biodegradável associada a diferentes temperaturas no controle e qualidade de frutos da goiabeira 'Paluma' infestados por Ceratitis capitata Wiedemann. O experimento foi conduzido em delineamento inteiramente casualizado em esquema fatorial $3 \times 6 \times 6$ com três repetições. Os fatores em estudo foram três temperaturas $10{ }^{\circ} \mathrm{C}, 15^{\circ} \mathrm{C}$ e $23{ }^{\circ} \mathrm{C}$ (temperatura ambiente) com seis tratamentos cada: Controle - SO SR (sem oviposição e sem recobrimento); CO SR (com oviposição e sem recobrimento); SO+RCOE (sem oviposição e recobrimento contendo óleo de erva-doce); $\mathrm{CO}+\mathrm{RCOE}$ (com oviposição e recobrimento contendo óleo de erva-doce); SO+RCOM (sem oviposição e recobrimento contendo óleo de manjericão) e $\mathrm{CO}+\mathrm{RCOM}$ (com oviposição e recobrimento contendo óleo de manjericão). Os tratamentos foram avaliados em seis períodos conforme os fatores já mencionados. Foram realizadas avaliações físicas, físico-químicas, bioquímicas e avaliações subjetivas. Os dados foram submetidos à análise de variância com base na significância do teste $\mathrm{F}$ e, para testar o efeito dos dias de armazenamento, os resultados foram submetidos à análise de regressão. $O$ uso de recobrimento biodegradável associado a temperaturas baixas minimizar a perda de massa e promove menor perda de firmeza dos frutos. A presença de larvas de C. capitata deprecia a qualidade físico-química dos frutos de goiaba, entretanto o processo de recobrimento associado a temperaturas baixas é letal a ovos e larvas de C. capitata, reduzindo os danos em frutos infestados.

Palavras-chave: Psidium guajava. Ceratitis capitata. Recobrimento biodegradável. Temperaturas.

\footnotetext{
${ }^{*}$ Corresponding author

${ }^{1}$ Received for publication in $02 / 26 / 2019$; accepted in $11 / 28 / 2019$.

Paper extracted from the doctoral thesis of the first author.

${ }^{2}$ Universidade Federal da Paraíba, Areia, PB, Brazil; joalissongs@yahoo.com.br - ORCID: 0000-0001-5890-3833, roberio_b19@yahoo.com.br - ORCID: 0000-0002-4590-9934, lucasgomesrdg@gmail.com - ORCID: 0000-0003-4847-2149.

${ }^{3}$ Departament of Biological Sciences, Universidade Federal da Paraíba, Areia, PB, Brazil; carlos@cca.ufpb.br - ORCID: 0000-0002-01950986.

${ }^{4}$ Departament of Rural Technology, Universidade Federal da Paraíba, Bananeiras, PB, Brazil; laesiopm@gmail.com - ORCID: 0000-00023252-0807.
} 


\section{INTRODUCTION}

Guava (Psidium guajava L.) is widely cultivated in tropical and subtropical regions of the world, being cultivated in Brazil from north to south. It is quite appreciated for its organoleptic characteristics, suitability for both industry and fresh consumption, and high nutritional content (ABREU et al., 2012). Although it is endowed with these positive features, this crop has been greatly compromised due to the attack of several pests, which damage the fruits and make them unsuitable for industrialization and commercialization, due to the phytosanitary barriers imposed by importing countries (SANTOS et al., 2011).

The incidence of fruit flies (Diptera: Tephritidae) is a serious problem in the northeast region, resulting in production losses and increased production costs, due to the application of insecticides. In addition, the insecticides used in control cause negative impacts on the beneficial entomofauna, besides being harmful to human health and the agroecosystem (AZEVEDO et al., 2010). The mechanical injuries caused by these Tephritidae, in addition to changing fruit appearance, stimulate the production of ethylene, accelerating the ripening and, consequently, reducing their commercialization time (HENRIQUE; CEREDA; SARMENTO, 2008; ALMEIDA, 2010). The main forms used to maintain the quality of these fruits are the use of polymeric coatings, cooling, modified atmosphere packaging and irradiation (CHITARRA; CHITARRA, 2005).

The use of biodegradable coatings has received attention due to their barrier properties to the gaseous exchanges, improving the appearance and structural integrity (JACOMINO et al., 2003). In addition, it has the potential to incorporate essential oils in the cassava starch biofilm matrix to serve as an antimicrobial agent for bacteria (KECHICHIAN et al., 2010) and control economically important insects such as fruit flies (CARVALHO, 2010). Biodegradable coatings act as semi-permeable barriers which may be able to maintain the quality of the food.

The modified atmosphere created by these coatings generates a physical capture of $\mathrm{CO}_{2}$ inside the fruit and a partial seal of the pores, reducing the rate of gas transfer (LIMA et al., 2010), and therefore the metabolic rate of the fruits. This technology associated with cooling, in addition to delaying the ripening, keeps the postharvest quality of fruits (CHITARRA; CHITARRA, 2005).

Considering the importance of the guava crop and the damage caused by fruit flies in the postharvest phase, this study aimed to evaluate the effect of the use of biodegradable coating associated with different temperatures on the quality of 'Paluma' guava fruits infested by Ceratitis capitata Wiedemann and on its control.

\section{MATERIAL AND METHODS}

'Paluma' guava fruits were purchased in the local market with yellowish-green peel color and were transported in boxes to the laboratory for the process of fruit fly oviposition.

The fruits were selected and randomly separated into six batches of 45 fruits and three batches were subjected to fruit fly ( $C$. capitata) oviposition, for a period of 24 hours at a temperature of $25{ }^{\circ} \mathrm{C}$. After the period of oviposition, fruits were transported to the laboratory of post-harvest for application of biodegradable coating, made from cassava (Manihot esculenta Crantz) starch at 3.0\%, glycerol at $1.0 \%$ and fennel (Foeniculum vulgare Mill.) oil at $0.03 \%$ or basil (Ocimum basilicum L.) oil at $0.03 \%$ dissolved in Tween 40 (1:1). The fruits were immersed in coating solution for an average period of 20 to 30 seconds and then dried on benches.

The experiment was conducted in a completely randomized design in $3 \times 6 \times 6$ factorial arrangement with three replications, and each repetition consisted of three fruits. The factors under study were three temperatures: $10^{\circ} \mathrm{C}, 15^{\circ} \mathrm{C}$, and 23 ${ }^{\circ} \mathrm{C}$ (room temperature), with six treatments each: Control - WoO WoC (without oviposition and without coating); WiO WoC (with oviposition and without coating); $\mathrm{WoO}+\mathrm{CCFO}$ (without oviposition and coating containing fennel oil); $\mathrm{WiO}+\mathrm{CCFO}$ (with oviposition and coating containing fennel oil); $\mathrm{WoO}+\mathrm{CCBO}$ (without oviposition and coating containing basil oil); $\mathrm{WiO}+\mathrm{CCBO}$ (with oviposition and coating containing basil oil). The treatments were evaluated in six periods according to the factors already mentioned: pre-oviposition, 4, 8, 12, 16 and 20 days after oviposition, for the fruits under controlled temperatures $\left(10{ }^{\circ} \mathrm{C}\right.$ and $\left.15{ }^{\circ} \mathrm{C}\right)$; and preoviposition, $2,4,6,8$ and 10 days after oviposition, for fruits kept at $23{ }^{\circ} \mathrm{C}$.

Physical evaluations: Loss of fresh mass (PP) in percentage - Calculated by reference to the initial weight of guavas, for each review period, using semi -analytical scale; and peel firmness $(\mathrm{N})$ : Determined using a manual penetrometer with socket of $8 \mathrm{~mm}$ in diameter, on two opposite sides of the equatorial region of the fruit.

Physicochemical evaluations: Soluble solids (SS) - Determined with digital refractometer, with results expressed in \%; titratable acidity (TA) Determined by titrimetry with $0.1 \mathrm{M} \mathrm{NaOH}$ and expressed as (\%) of citric acid; ascorbic acid (AA) (mg.100 $\mathrm{g}^{-1}$ ) - Determined by titration with 2.6 dichlorophenol-indophenol (DPI), until obtaining clear permanent pinkish color, using $1.0 \mathrm{~g} \mathrm{~L}^{-1}$ of the pulp diluted in $30.0 \mathrm{~mL} \mathrm{~L}^{-1}$ of $0.5 \%$ oxalic acid; and hydrogen potential $(\mathrm{pH})$ - Determined using approximately $10.0 \mathrm{~mL} \mathrm{~L}^{-1}$ of the sample with a digital $\mathrm{pH}$ meter Digimed DM (-320) (ZENEBON; PASCUET; TIGLEA, 2008). 
Biochemical analyses: Total carotenoids Determined by spectrophotometry read in a spectrophotometer at a wavelength of $450 \mathrm{~nm}$; and lycopene - Determined by spectrophotometry read in a spectrophotometer at a wavelength of $630 \mathrm{~nm}$ (HIGBY, 1962).

Subjective evaluations: General appearance (AP) - 1= Complete loss of turgidity, brightness and color, wilted surface, fungal development, advanced senescence, useless for consumption; 3= Accentuated wilting, without apparent brightness and total loss of aroma, presence of external stains, symptoms of senescence and/or decay; 5= Little freshness, slight loss of turgidity, loss of brightness, slightly attractive look, absence of diseases, external stains and/or decay; 7= Fresh fruit, turgid, surface showing little intense brightness, absence of dark spots or diseases; 9= Fresh fruit, turgid, glossy surface, healthy, attractive, free of pathogens and damage and/or rotting (SANTOS, 2006).

The number of larvae per fruit was counted 20 days after oviposition for the treatments under controlled temperature $\left(10{ }^{\circ} \mathrm{C}\right.$ and $\left.15^{\circ} \mathrm{C}\right)$ and at 10 days after oviposition for the treatments at $23{ }^{\circ} \mathrm{C}$. The data were subjected to analysis of variance and, based on the significance of the F test, polynomial
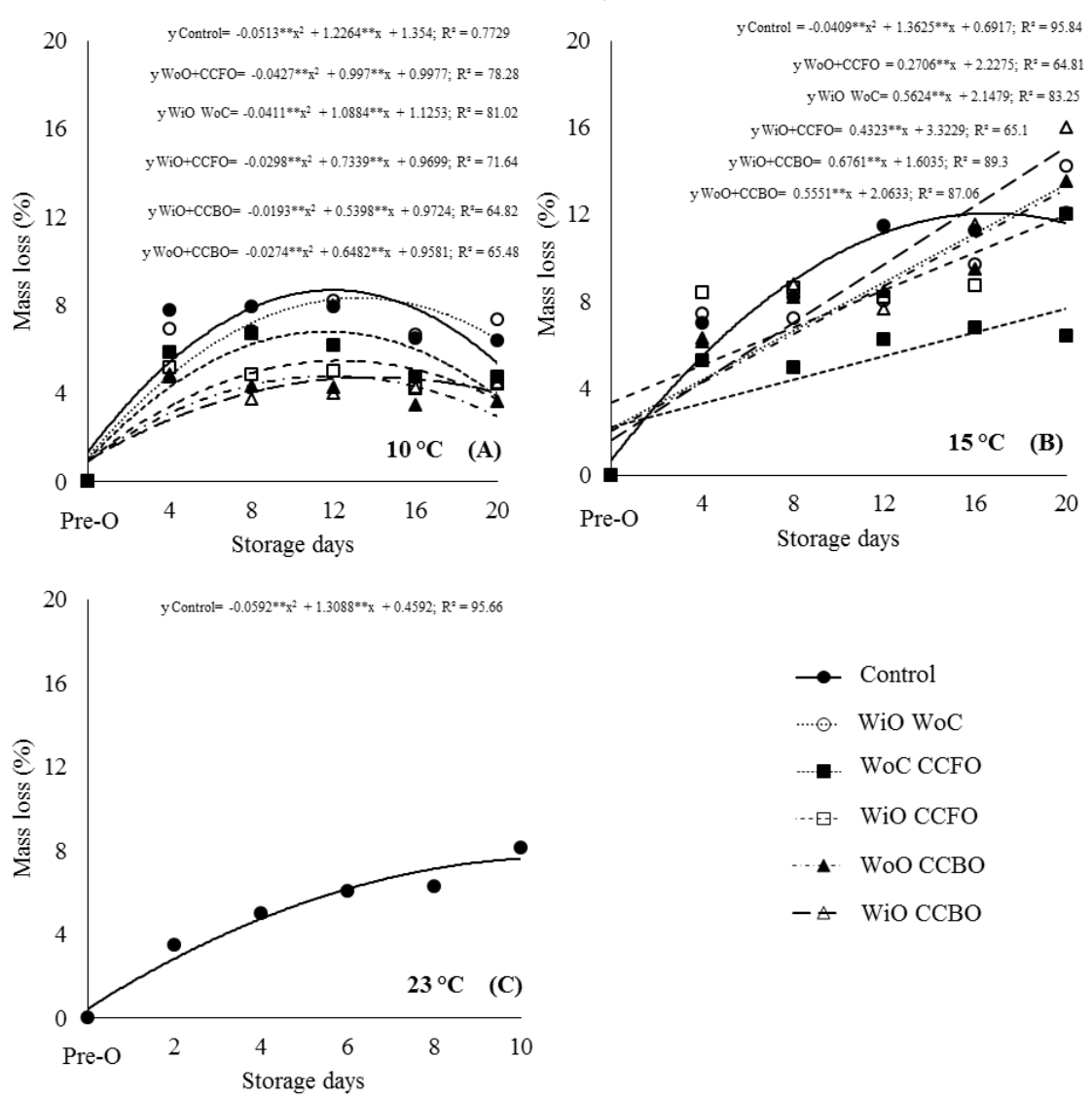

Figure 1. Mass loss of 'Paluma' guava fruits subjected (WiO) or not (WoO) to oviposition by fruit flies (Ceratitis capitata) for 24 hours and subsequently treated (WiC) or not (WoC) with biodegradable film of cassava (Manihot esculenta) starch and oil of fennel (Foeniculum vulgare) (CCFO) or basil (Ocimum basilicum) (CCBO) and stored at $10{ }^{\circ} \mathrm{C}$ and $15{ }^{\circ} \mathrm{C}$ for 20 days and at $23{ }^{\circ} \mathrm{C}$ (room temperature) for 10 days. Control (WoO WoC). Pre-oviposition (Pre-O). regression analysis was used to test the effect of days of storage, being tested up to the quadratic level, considering the significance of up to $5.0 \%$ of probability and coefficient of determination $\left(\mathrm{R}^{2}\right)$ above $60.0 \%$. Pearson correlation analysis, principal components analysis (PCA) and hierarchical cluster analysis were also performed. SAS software 9.3 (2011) and JMP ${ }^{\circledR}$ 10.0.0 were used for the analyses.

\section{RESULTS AND DISCUSSION}

According to the results, it was found that the loss of mass of 'Paluma' guavas for the evaluated treatments varied depending on the use of coating and temperatures, with the exception of treatments at temperature of $23{ }^{\circ} \mathrm{C}$. During the ten days of storage there was no significant difference between the treatments applied to the stored fruits, indicating that the treatments $(\mathrm{WiO} \mathrm{WoO})$ and $(\mathrm{WiC} \mathrm{WoC})$ did not cause a significant loss, but there was a difference between the storage periods, and this variable increased with the passing of days, as the high temperature promoted an increase of respiratory rate, earlier ripening and reduction of fresh mass (Figure 1 C).

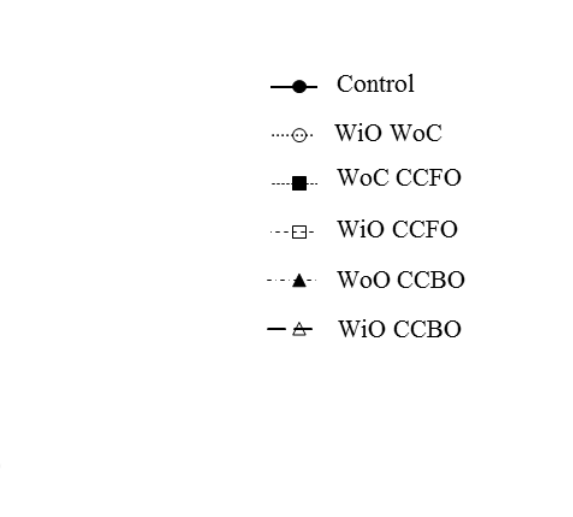

Rev. Caatinga, Mossoró, v. 33, n. 1, p. 62 - 71, jan. - mar., 2020 
Regarding the fruits under lower temperature $\left(10{ }^{\circ} \mathrm{C}\right.$ and $\left.15^{\circ} \mathrm{C}\right)$, it was observed that a growing loss occurred in the course of storage during the 20 days; however, the fruits with greater mass loss were those from the control (WoO WoC) and $\mathrm{WiO} \mathrm{WoC}$ treatments, which were the ones that did not receive any type of coatings, different from the other treatments, which received such coatings. On the other hand, at a temperature of $15{ }^{\circ} \mathrm{C}$, it was observed that the largest mass loss was found in the treatments that underwent oviposition by fruit flies ( $\mathrm{WiO} \mathrm{WoC}$ and $\mathrm{WiO}+\mathrm{CCBO}$ ) (Figure $1 \mathrm{~A}$ and $\mathrm{B}$ ).

Upon using these coatings, it is expected that they restrict the diffusion of water vapor and create a saturated atmosphere between the film and the fruit surface, reducing transpiration. However, due to the hydrophilic nature of the coatings based on polysaccharides, these generally do not constitute barriers to water vapor (SIQUEIRA, 2012). Therefore, adding glycerol and Tween 40 to these coatings, which together improve the barrier property of starch, reduces the loss of water through transpiration. Similar results were also observed for the coatings with cassava starch associated with essential oil in mangoes at different storage temperatures (AZEVEDO, 2016)

In the infested fruits, the process intensified the rate of mass loss, increasing the surface/volume ratio of fruits, exposing the tissue to the atmosphere, facilitating the loss of water and consequently loss of fresh mass.

There was a significant interaction between the applied treatments, the temperature and period of storage in relation to guava firmness (Figure 2). In general, it was observed that the temperature directly influences fruit firmness, where the temperature of $10{ }^{\circ} \mathrm{C}$ maintained higher firmness when compared with the others $\left(15{ }^{\circ} \mathrm{C}\right.$ and $\left.23{ }^{\circ} \mathrm{C}\right)$. It was also observed that with the passing of days of storage the fruits suffered greater loss of firmness. With the evolution of maturation, there is an increase in the activity of pectinolytic enzymes, which transform the soluble and insoluble pectin and promote fruit softening.

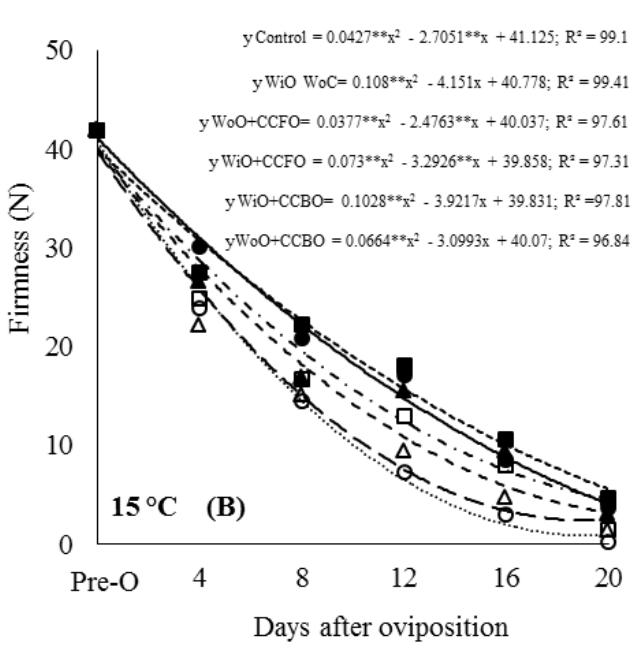

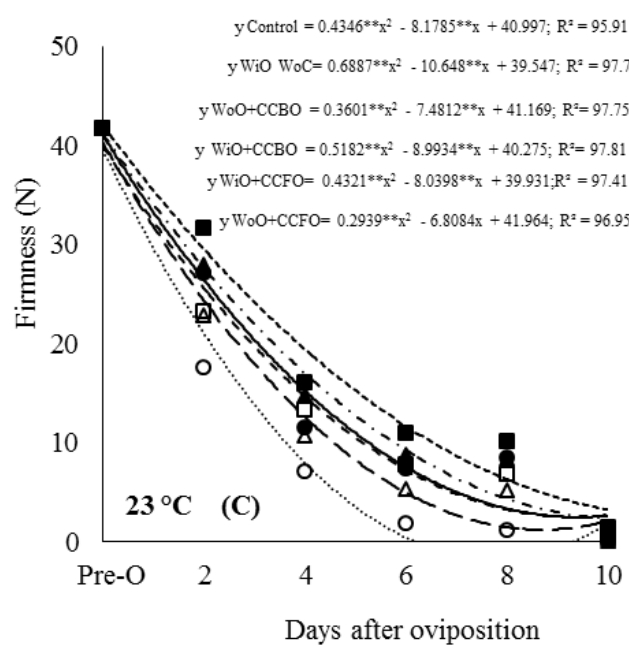

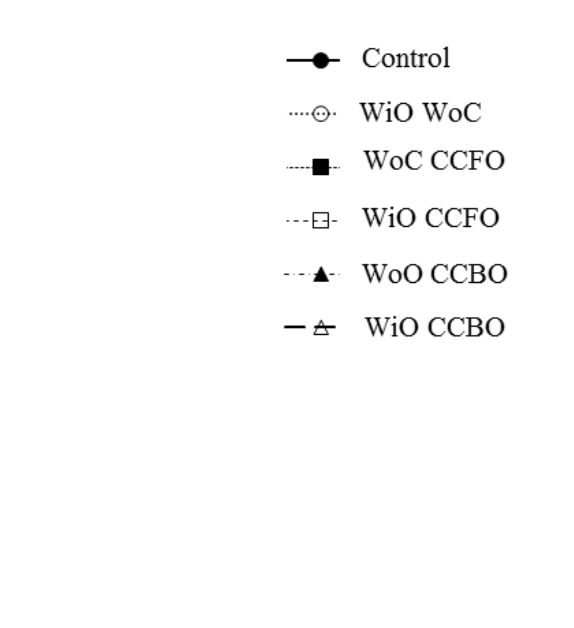

Figure 2. Firmness of 'Paluma' guava fruits subjected (WiO) or not (WoO) to oviposition by fruit flies (Ceratitis capitata) for 24 hours and subsequently treated (WiC) or not (WoC) with biodegradable film of cassava (Manihot esculenta) starch and oil of sweet fennel (Foeniculum vulgare) (CCFO) or basil (Ocimum basilicum) (CCBO) and stored at $10{ }^{\circ} \mathrm{C}$ and $15{ }^{\circ} \mathrm{C}$ for 20 days and at $23{ }^{\circ} \mathrm{C}$ (room temperature) for 10 days. Control (WoO WoC). Pre-oviposition (Pre-O).

Rev. Caatinga, Mossoró, v. 33, n. 1, p. 62 - 71, jan. - mar., 2020 
Regression analysis showed that the best results were achieved by the treatments without oviposition and which received coating (Figure 2). The treatments $\mathrm{WoO}+\mathrm{CCFO}$ and $\mathrm{WoO}+\mathrm{CCBO}$ were efficient and promoted greater firmness, when compared to the treatment $\mathrm{WiO} \mathrm{WoC}$, which led to zero firmness on the sixth day of storage at temperature of $23{ }^{\circ} \mathrm{C}$. The reduction of firmness in these fruits subjected to the oviposition process is attributed to the chemical modifications and degradation of the cell wall components that the fruit flies larvae promote in the body, thus diminishing

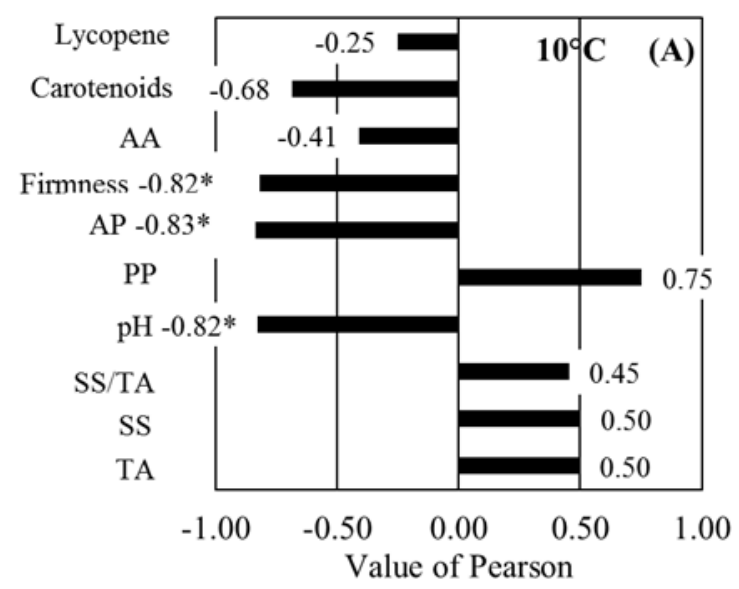

fruit integrity. The decrease in fruit firmness contributes to a greater susceptibility to the attack of microorganisms and to a lower impact resistance.

The attributes of physical, physicochemical, sensory and bioactive qualities were correlated with the number of larvae present in fruits, under different storage conditions/temperatures (Figure $3 \mathrm{~A}, \mathrm{~B}$, and C). Thus, it is possible to observe how the presence of larvae depreciated the quality in 'Paluma' guava fruits, through the values of negative correlation with one another at both storage temperatures.

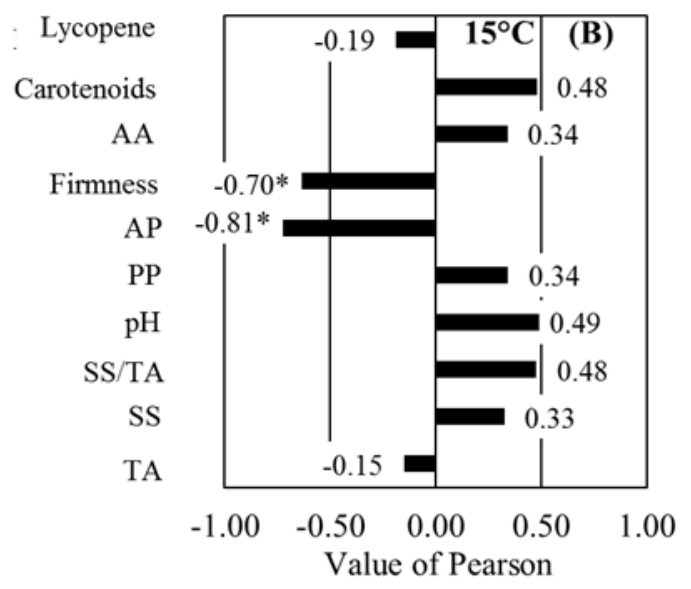

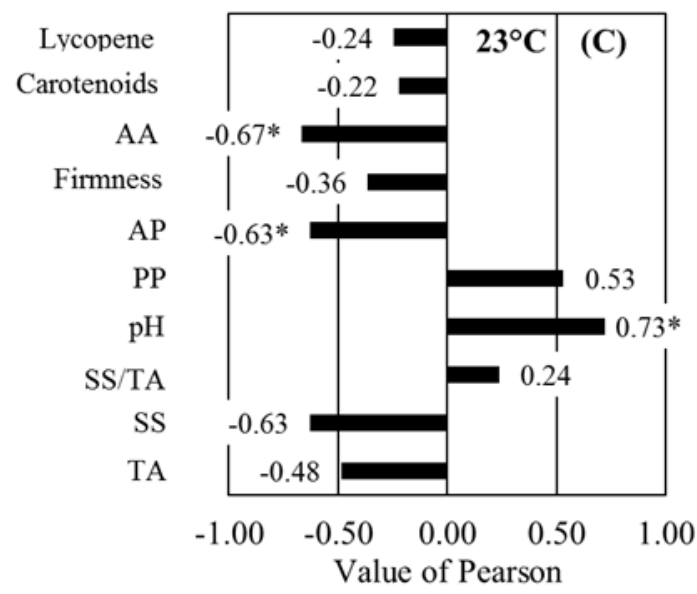

Figure 3. Pearson correlation of the number of larvae per fruit with the variables related to the changes in the quality of 'Paluma' guava fruits subjected (WiO) or not (WoO) to oviposition by fruit fly (Ceratitis capitata) for 24 hours and subsequently treated $(\mathrm{WiC})$ or not $(\mathrm{WoC})$ with biodegradable film of cassava (Manihot esculenta) starch and oil of sweet fennel (Foeniculum vulgare) (CCFO) or basil (Ocimum basilicum) (CCBO) and stored at $10^{\circ} \mathrm{C}$ and $15{ }^{\circ} \mathrm{C}$ for 20 days and at $23{ }^{\circ} \mathrm{C}$ (room temperature) for 10 days. Control (WoO WoC). AA = ascorbic acid. AP = appearance. $\mathrm{pH}=$ hydrogen potential. $\mathrm{PP}=$ Mass loss. $\mathrm{SS}=$ soluble solids. $\mathrm{TA}=$ titratable acidity.

Fruit firmness showed a strong negative correlation with the number of larvae, especially at temperatures of $10^{\circ} \mathrm{C}$ and $15^{\circ} \mathrm{C}$ (Pearson values of 0.82 and -0.70 , respectively), possibly due to the galleries caused by larvae with consequent softening of pulp. This stress on the fruits also accelerates the processes of degradation of cell wall, favoring ionic changes in the apoplast, mainly by reducing the $\mathrm{pH}$ (ALMEIDA; HUBER, 2001), as it can be confirmed by the strong negative correlation $(r=-0.82)$ for $\mathrm{pH}$ at temperature of $10{ }^{\circ} \mathrm{C}$, where the correlation between firmness and number of larvae was higher. Consequently, fruit appearance was depreciated and strong negative correlations between the number of larvae and the appearance (AP) by sensory evaluation were observed at both storage temperatures $(r=-0.83,-0.81$ and -0.63 at temperatures of $10{ }^{\circ} \mathrm{C}, \quad 15{ }^{\circ} \mathrm{C}$, and $23{ }^{\circ} \mathrm{C}$, respectively). 
At the temperature of $10{ }^{\circ} \mathrm{C}, \mathrm{pH}$ had a strong correlation and a negative correlation with the number of larvae in the fruits (Pearson value of 0.82 ); on the other hand, at a temperature of $23{ }^{\circ} \mathrm{C}$ the correlation between $\mathrm{pH}$ and number of larvae was strongly positive $(r=0.73)$. At room temperature, fruit metabolism becomes more pronounced (TOIVONEN; BRUMMELL, 2008), especially with the adverse effects of the presence of larvae, favoring also a greater consumption of organic acids, as it can be observed by the values of the negative correlation between ascorbic acid and number of larvae $\left(r=-0.67\right.$ at $\left.23{ }^{\circ} \mathrm{C}\right)$ and with less intensity between titratable acidity and number of larvae $\left(r=-0.48^{\text {ns }}\right.$ at $\left.23{ }^{\circ} \mathrm{C}\right)$.

The loss of mass (PP) always showed positive correlation values with the number of larvae in the fruits, under all conditions of storage, and although not significant they indicate one more quality attribute depreciated by the presence of larvae. At the temperature $23{ }^{\circ} \mathrm{C}$, there were still negative correlation values for the contents of soluble solids $\left(r=-0.63^{\mathrm{ns}}\right)$, lycopene $\left(r=-0.24^{\mathrm{ns}}\right)$ and carotenoids $(r$ $\left.=-0.22^{\mathrm{ns}}\right)$ with the number of larvae in the fruits. Together, the correlation of all quality attributes with the number of larvae ratifies the physiological disorders and the depreciation of fruit quality caused by fruit fly.

The principal components analysis (PCA) was performed for each condition/storage temperature and explained $82.30 \%, 72.10 \%$, and $72.60 \%$ of the variability among the treatments with only two principal components at temperatures of $10{ }^{\circ} \mathrm{C}, 15^{\circ}$ $\mathrm{C}$, and $23{ }^{\circ} \mathrm{C}$, respectively. In Table 1 , it is possible to observe a description of the contributions of the variables for the first two principal components in each PCA and that, on the other hand, they reflect good overall similarity with the grouped treatments (Figure 5). Together, the projection of the values of Loading and Score along with the Dendrograms describe the contributions of variables for each group and the overall differences among the different treatments.

Table 1. Eigenvectors of two principal components ( $\mathrm{PC} 1$ and $\mathrm{PC} 2)$ of variables related to the changes in the quality of 'Paluma' guava fruits subjected (WiO) or not (WoO) to oviposition by the fruit fly (Ceratitis capitata) for 24 hours and subsequently treated (WiC) or not (WoC) with biodegradable film of cassava (Manihot esculenta) starch and oil of sweet fennel (Foeniculum vulgare) (CCFO) or basil (Ocimum basilicum) (CCBO) and stored at $10{ }^{\circ} \mathrm{C}$ and $15{ }^{\circ} \mathrm{C}$ for 20 days and at $23{ }^{\circ} \mathrm{C}$ (room temperature) for 10 days. Control $(\mathrm{WoO} \mathrm{WoC})$. $\mathrm{AA}=$ ascorbic acid. $\mathrm{AP}=$ appearance. $\mathrm{pH}=$ hydrogen potential. $\mathrm{SS}=$ soluble solids. $\mathrm{TA}=$ titratable acidity. $\mathrm{VitC}=$ vitamin $\mathrm{C}$.

\begin{tabular}{|c|c|c|c|c|c|c|}
\hline \multirow{3}{*}{ Variables } & \multicolumn{6}{|c|}{ Eigenvectors } \\
\hline & \multicolumn{2}{|c|}{$10^{\circ} \mathrm{C}$} & \multicolumn{2}{|c|}{$15^{\circ} \mathrm{C}$} & \multicolumn{2}{|c|}{$23^{\circ} \mathrm{C}$} \\
\hline & $\mathrm{PC} 1$ & $\mathrm{PC} 2$ & $\mathrm{PC} 1$ & $\mathrm{PC} 2$ & $\mathrm{PC} 1$ & $\mathrm{PC} 2$ \\
\hline TA & -0.31234 & 0.19881 & -0.31778 & 0.39037 & 0.38296 & -0.08977 \\
\hline SS & -0.33371 & 0.22883 & 0.10120 & 0.47602 & 0.38531 & -0.16774 \\
\hline $\mathrm{SS} / \mathrm{TA}$ & -0.32060 & 0.23044 & 0.35343 & 0.20506 & -0.34413 & 0.00160 \\
\hline $\mathrm{pH}$ & 0.32557 & 0.00295 & 0.38963 & -0.21043 & -0.36748 & 0.09109 \\
\hline Mass loss & -0.36021 & -0.01017 & 0.36215 & 0.04951 & -0.11792 & 0.45007 \\
\hline AP & 0.31066 & 0.38871 & $-\mathbf{0 . 3 6 2 0 7}$ & -0.24737 & 0.38043 & -0.07816 \\
\hline Firmness & 0.24603 & 0.49793 & -0.35043 & -0.06153 & 0.33804 & 0.00953 \\
\hline VitC & 0.20715 & $-\mathbf{0 . 3 7 0 9 7}$ & 0.16320 & -0.05858 & 0.20143 & 0.26406 \\
\hline Carotenoids & 0.33118 & 0.17005 & -0.04932 & 0.55632 & 0.10692 & 0.61436 \\
\hline Lycopene & 0.23002 & -0.44988 & -0.32650 & 0.27767 & 0.19710 & 0.54536 \\
\hline Number of larvae & -0.30003 & -0.29486 & 0.30224 & 0.27789 & -0.29606 & 0.04644 \\
\hline VA & 64.70 & 82.30 & 45.10 & 72.10 & 52.30 & 72.60 \\
\hline Eigenvalue & 7.1184 & 1.933 & 4.9625 & 2.9654 & 5.7563 & 2.2324 \\
\hline
\end{tabular}

Criteria used to separate the variables representing the component based on the modulus of ratio $0.7 \times$ highest Eigenvectors are highlighted in bold.

All studied variables demonstrated significant contribution, considering the minimum value based on modulus of the multiplication ratio $0.7 \times$ highest Eigenvectors, in the formation of the first two principal components (Table 1). Therefore, all quality attributes were considered important in the description of the formed groups and should be considered in future studies of fruit fly control from biodegradable coatings in guava fruits.

From the cluster analysis associated with PCA, three different groups can be distinguished in each storage condition (Figure 4). At a temperature of $10{ }^{\circ} \mathrm{C}$, the control along with the treatment $\mathrm{WiO}$ WoC clustered mainly because of the high content of 
SS, TA and SS/TA, but also showed higher loss of mass and number of larvae per fruit, especially for $\mathrm{WiO}$ WoC. In turn, the treatment $\mathrm{WoO}+\mathrm{CCFO}$ differed from all others, especially due to the greater firmness, better appearance for sensory evaluation and still considerable content of carotenoids. The
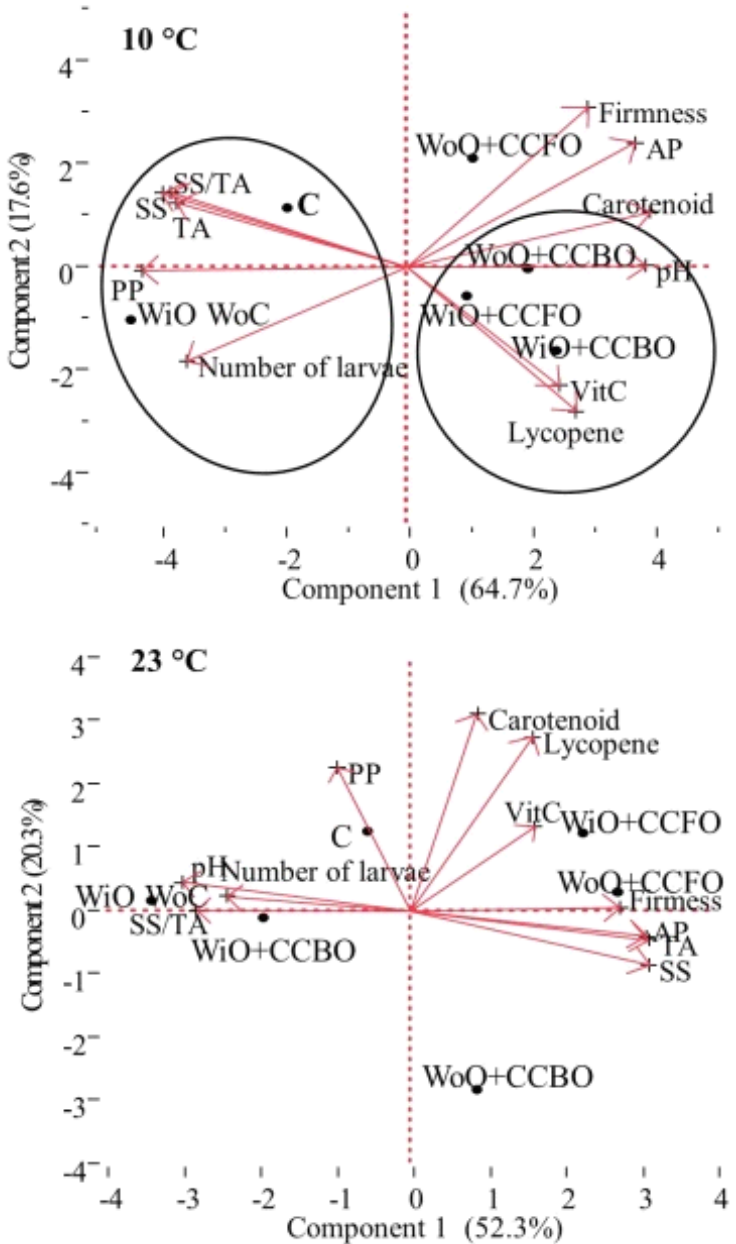

treatments $\mathrm{WoO}+\mathrm{CCBO}, \mathrm{WiO}+\mathrm{CCFO}$ and $\mathrm{WiO}+\mathrm{CCBO}$ showed great similarity among themselves, mainly for preserving the high contents of vitamin $\mathrm{C}$ and lycopene, combined with insignificant numbers of larvae and smaller loss of mass.
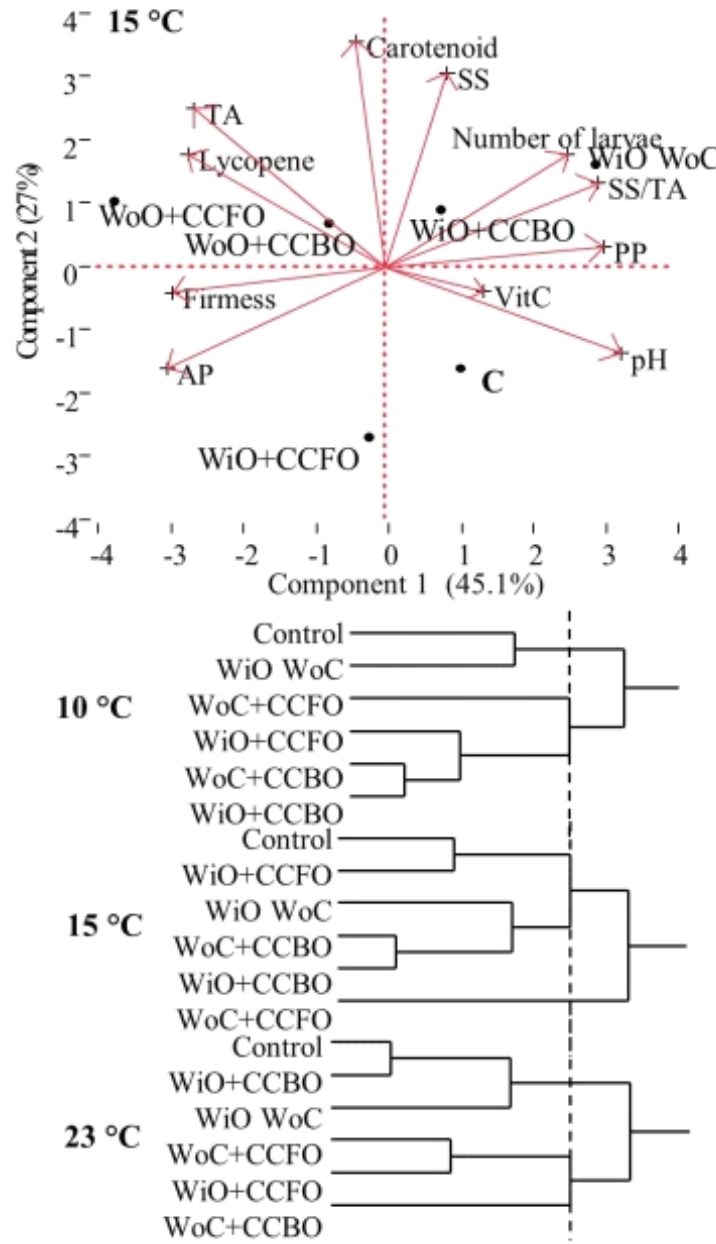

Figure 4. Projection of values of Loading (variables) and Score (treatments) of two principal components (PC1 and PC2) of variables related to the changes in the quality of 'Paluma' guava fruits subjected (WiO) or not (WoO) to oviposition by the fruit fly (Ceratitis capitata) for 24 hours and subsequently treated (WiC) or not (WoC) with biodegradable film of cassava (Manihot esculenta) starch and oil of fennel (Foeniculum vulgare) (CCFO) or basil (Ocimum basilicum) (CCBO) and stored at $10{ }^{\circ} \mathrm{C}$ and $15{ }^{\circ} \mathrm{C}$ for 20 days and at $23{ }^{\circ} \mathrm{C}$ (room temperature) for 10 days. Control (WoO WoC). $\mathrm{AA}=$ ascorbic acid. $\mathrm{AP}=$ appearance. $\mathrm{pH}=$ hydrogen potential. $\mathrm{PP}=$ Mass loss. $\mathrm{SS}=$ soluble solids. $\mathrm{TA}=$ titratable acidity. Vit $\mathrm{C}=$ vitamin $\mathrm{C}$.

At the temperature of $15{ }^{\circ} \mathrm{C}$ the control and $\mathrm{WiO}+\mathrm{CCFO}$ showed great similarity to each other and differed from the other treatments primarily because of the low contents of soluble solids and carotenoids. The treatments WiO WoC, $\mathrm{WoO}+\mathrm{CCBO}$, and $\mathrm{WiO}+\mathrm{CCBO}$ clustered among themselves with intermediate values for both traits, except for the WiO WoC treatment, which had a considerable number of larvae in the fruits and low values of score for appearance. In turn, the treatment $\mathrm{WoO}+\mathrm{CCFO}$ is distinguished from all others for promoting lower mass loss, low $\mathrm{pH}$, higher content of lycopene, in addition to good scores of appearance and medium firmness.
At $23{ }^{\circ} \mathrm{C}$, the control, $\mathrm{WiO}$ WoC and $\mathrm{WiO}+\mathrm{CCBO}$ differed from the others for having higher $\mathrm{pH}$ and SS/TA, lower firmness, SS, and TA, in addition to lower scores of appearance. In turn, the treatments $\mathrm{WiO}+\mathrm{CCFO}$ and $\mathrm{WoO}+\mathrm{CCFO}$ showed higher firmness, titratable acidity, scores of appearance, and considerable contents of lycopene, carotenoids and vitamin $\mathrm{C}$. The treatment $\mathrm{WoO}+\mathrm{CCBO}$, in turn, showed the lowest contents of carotenoids and lycopene, indicating fruits under low levels of stress.

Together, PCA demonstrated that biodegradable coatings containing essential oils applied in fruits after being attacked by fruit flies 
inhibit the development of larvae and retain a set of characteristics similar those of fruits that were not subjected to oviposition.

The efficiency of the treatment was verified by the proportion of hatched eggs of $C$. capitata as a function of the temperature and the type of coating after being artificially infested. Larval survival evaluations were performed after ten days for $23{ }^{\circ} \mathrm{C}$ and 20 days for the controlled temperatures $\left(10{ }^{\circ} \mathrm{C}\right.$ and $15^{\circ} \mathrm{C}$ ), by counting the number of larvae per fruit.

It was observed that the effect of temperature was paramount on the development of $C$. capitata,

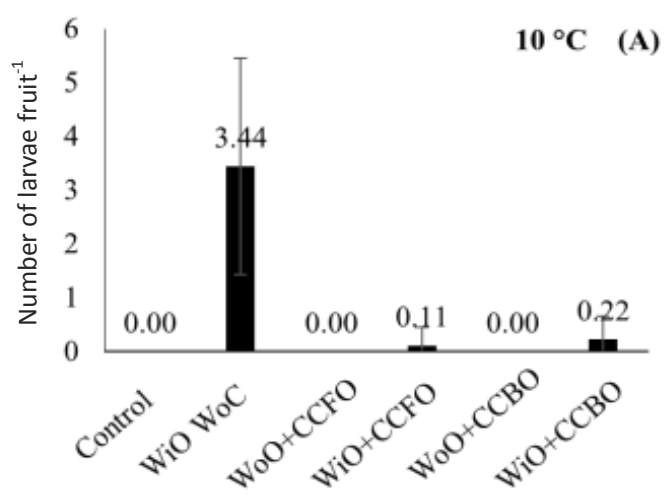

that is, lower temperatures promoted a reduction in the number of larvae, which averaged $3.44,6.22$, and 27.22 units per fruit at temperatures of $10{ }^{\circ} \mathrm{C}, 15^{\circ} \mathrm{C}$, and $23{ }^{\circ} \mathrm{C}$, respectively, in fruits not treated with coating. Considering that the temperature influences the development speed of the insects because they are poikilothermic (body temperature varies according to the room temperature) (CENTENO; MALDONADO; OLIVA, 2002), it was possible to observe the influence of lower temperatures as the main causative factor of mortality in eggs and larvae of $C$. capitata present in guava fruits (Figure 5).

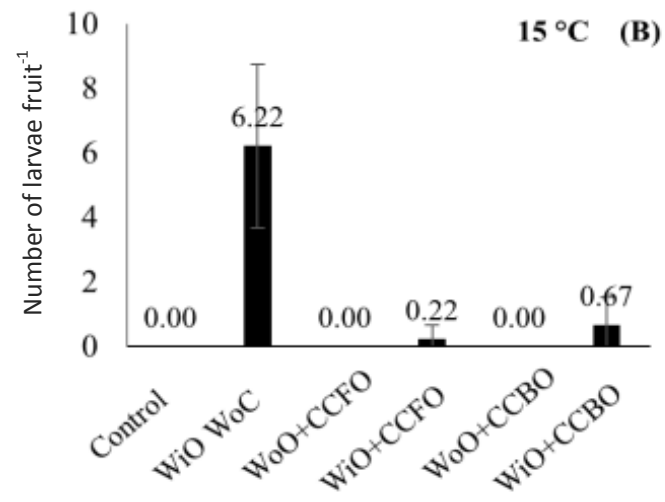

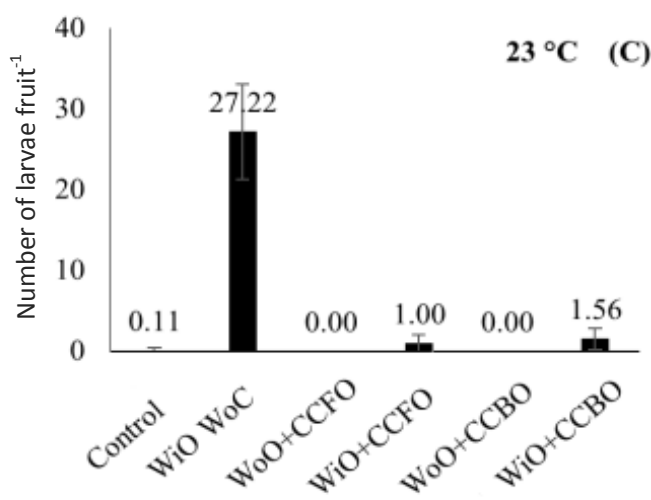

Figure 5. Number of larvae per fruit of 'Paluma' guava subjected (WiO) or not (WoO) to oviposition by fruit flies (Ceratitis capitata) for 24 hours and subsequently treated (WiC) or not (WoC) with biodegradable film of cassava (Manihot esculenta) starch and oil of fennel (Foeniculum vulgare) (CCFO) or basil (Ocimum basilicum) (CCBO) and stored at $10{ }^{\circ} \mathrm{C}$ and $15{ }^{\circ} \mathrm{C}$ for 20 days and at $23{ }^{\circ} \mathrm{C}$ (room temperature) for 10 days. Control (WoO WoC).

For temperatures of $10{ }^{\circ} \mathrm{C}, 15^{\circ} \mathrm{C}$ and $23^{\circ} \mathrm{C}$, the application of the coatings decreased by $96.81 \%$ and $93.11 \%, 96.47 \%$ and $89.23 \%$, and $96.33 \%$ and $94.27 \%$ the incidence of larvae for coatings with oils of sweet fennel and basil, respectively. Fruits with oviposition and without application of the coating showed 3.44, 6.22, and 27.22 larvae per unit of fruit. On the other hand, fruits with oviposition and treated with coating with oil of sweet fennel and basil had 0.11 and $0.22,0.22$ and 0.67 , and 1.00 and 1.56 larvae per unit of fruit, respectively. In addition, most larvae found in fruits with coating did not have any mobility, which indicates that they are dead. In the fruits that were not subjected to the oviposition the presence of larvae was not observed, thus indicating that the fruits used in the experiment were free of initial infestation of the pest, with the exception of the control treatment at $23{ }^{\circ} \mathrm{C}$, which had 0.11 larvae per unit of fruit (Figure 5). 
It is well known that fruits treated with coating and cooled have lower percentage of $\mathrm{CO}_{2}$ released, probably due to the restriction of gaseous exchange imposed by the film coating adhered to the fruit and the lower metabolism due to lower temperature $\left(10^{\circ} \mathrm{C}\right.$ and $\left.15^{\circ} \mathrm{C}\right)$. The fruits treated and not treated with biodegradable coating based on cassava starch and associated with the oils of sweet fennel and basil, when stored under refrigeration, showed on average lower infestation (ratio larvae per fruit) when compared to fruits with oviposition and without coating ( $\mathrm{WiO} \mathrm{WoC}$ ), stored at temperature $23{ }^{\circ} \mathrm{C}$. This result highlights the primary importance of the parameter temperature (cooling) and the secondary importance of the coating in the lethal effect at the initial stages (eggs and larvae) of the biological cycle of $C$. capitata.

It is possible that the changes in terms of exchanges that occur, resulting from the application of the coating on the fruit, promoted an increase in internal $\mathrm{CO}_{2}$ concentration due to the restriction imposed by coating, which interferes in gaseous exchanges, changing the internal $\mathrm{CO}_{2}$ concentration of the fruit and probably causing toxic effect. These results agree with those of Kester and Fennema (1986), in that the coating adhered to the fruit acts in a similar manner to the modified atmosphere.

\section{CONCLUSIONS}

The use of biodegradable coating associated with low temperatures minimizes the loss of mass and promotes lower loss of fruit firmness, in addition to preserving the quality of the external appearance of the fruit and prolong the shelf life period.

The presence of Ceratitis capitata larvae depreciates the physicochemical quality of 'Paluma' guava fruits.

The coating process associated with low temperatures promotes lethal effect on eggs and larvae of $C$. capitata, reducing damage and larvae survival in infested fruits.

\section{ACKNOWLEDGMENTS}

The authors also thank Coordination for the Improvement of Higher Education Personnel, for granting the scholarships.

\section{REFERENCES}

ABREU, J. R. et al. Histochemistry and morphoanatomy study on guava fruit during ripening. Ciência e Tecnologia de Alimentos, 32: 179-186, 2012.
ALMEIDA, D. M. Biofilme de blenda de fécula de batata e celulose bacteriana na conservação de fruta minimamente processada. $2010.283 \mathrm{f}$. Tese (Doutorado em Processos Biotecnológicos: Área de Concentração em Agroindústria) - Universidade Federal do Paraná, Curitiba, 2010.

ALMEIDA, D. P. F.; HUBER, D. J. Transient increase in locular pressure and occlusion of endocarpic apertures in ripening tomato fruit. Journal Plant Physiology, 158: 199-203, 2001.

AZEVEDO, F. R. et al. Análise faunística e flutuação populacional de moscas-das-frutas (Diptera: Tephritidae) em pomares comerciais de goiaba na região do Cariri Cearense. Arquivos do Instituto Biológico, 77: 33-41, 2010.

AZEVEDO, F. R. Efeito do ensacamento sobre a incidência de moscas-das-frutas e na qualidade das goiabas. Arquivos do Instituto Biológico, 83: 1-8, 2016 .

CARVALHO, R. S. Biofilme edível de amido de mandioca e refrigeração em goiaba cv. "Paluma" reduzem danos da mosca-do-mediterrâneo. In: CONGRESSO BRASILEIRO DE FRUTICULTURA, 21., 2010, Natal. Anais... Natal: EMPARN, UFERSA, Embrapa Tabuleiros Costeiros, 2010.

CENTENO, N.; MALDONADO, M.; OLIVA, A. Seasonal patterns of arthropods occurring on sheltered and unsheltered pig carcasses in Buenos Aires Province (Argentina). Forensic Science International, 126: 63-70, 2002.

CHITARRA, M. I. F.; CHITARRA, A. B. Póscolheita de frutas e hortaliças: fisiologia e manuseio. 2. ed. Lavras, MG: Rev. e Ampl., 2005. $783 \mathrm{p}$.

HENRIQUE, C. M.; CEREDA, M. P.; SARMENTO, S. B. S. Características físicas de filmes biodegradáveis produzidos a partir de amidos modificados de mandioca. Ciência e Tecnologia de Alimentos, 28: 231-240, 2008.

HIGBY, W. K. A simplified method for determination of some aspects of the carotenoid distribution in natural and carotene-fortified orange juice. Journal of Food Science, 27: 42-49, 1962.

JACOMINO, A. P. et al. Conservação de goiabas tratadas com emulsões de cera de carnaúba. Revista Brasileira de Fruticultura, 25: 401-405, 2003.

KECHICHIAN, V. et al. Natural antimicrobial ingredients incorporated in biodegradable films based on cassava starch. Food Science and 
Technology, 43: 1088-1094, 2010.

KESTER, J. J.; FENNEMA, O. R. Edible films and coatings: a review. Food Technology, 40: 47-59, 1986.

LIMA, A. M. et al. New edible coatings composed of galactomannans and collagen blends to improve the postharvest quality of fruits - influence on fruits gas transfer rate. Journal of Food Engineering, 97: 101 $-109,2010$.

SANTOS, A. F. Desenvolvimento e maturação de abacaxi e processamento mínimo de infrutescências colhidas sob boas práticas agrícolas e tratadas com 1-MCP. 2006. 224 f. Tese (Doutorado em Agronomia: Área de Concentração em Agricultura Tropical) - Universidade Federal da Paraíba, Areia, 2006.

SANTOS, M. S. et al. Análise faunística e flutuação populacional de moscas-das-frutas (Diptera: Tephritidae) em Belmonte, Bahia. Revista Caatinga, 24: 86-93, 2011.

SAS INSTITUTE. SAS user's guide: statistics. Software version 9.3. Cary, NC, USA, 2011.

SIQUEIRA, A. P. O. Uso de coberturas comestíveis na conservação pós-colheita de goiaba e maracujá-azedo. 2012. 91 f. Dissertação (Mestrado em Produção Vegetal: Área de Concentração em Produção Vegetal) - Universidade Estadual do Norte Fluminense Darcy Ribeiro, Rio de Janeiro, 2012.

TOIVONEN, P. M. A.; BRUMMELL, D. A. Biochemical bases of appearance and texture changes in fresh-cut fruit and vegetables. Postharvest Biology and Technology, 48: 1-14, 2008.

ZENEBON, O.; PASCUET, N. S.; TIGLEA, P. Métodos físico-químicos para análise de alimentos. 4. ed. São Paulo: SP, Instituto Adolfo Lutz, 2008. 1020 p. 